\title{
IMPLEMENTASI KURIKULUM BAHASA ARAB DI PERGURUAN TINGGI AGAMA ISLAM (PTAI) DI INDONESIA
}

Enjang Burhanudin Yusuf ${ }^{1}$

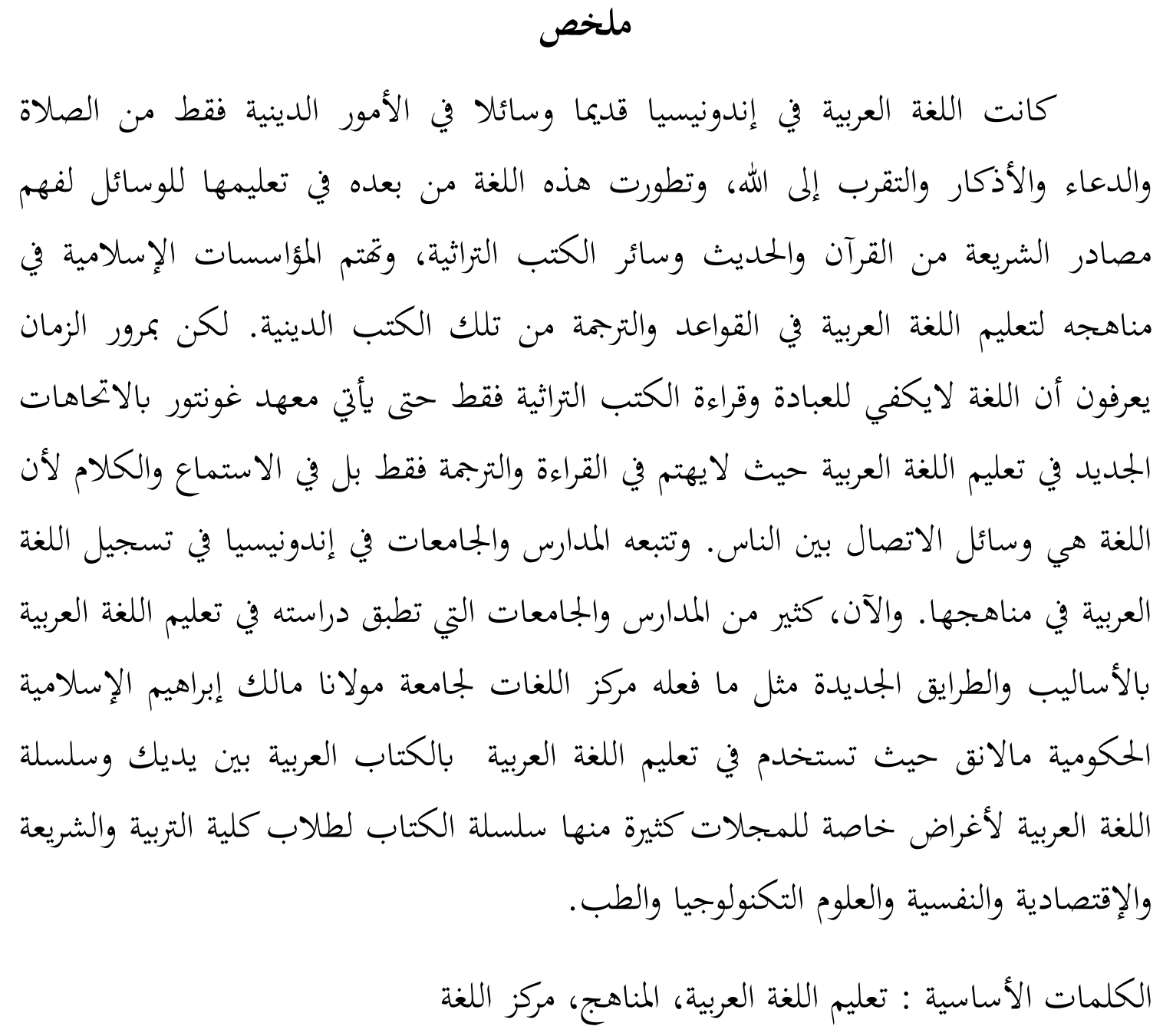

\section{A. Pendahuluan}

Usaha untuk mengajarkan bahasa arab di indonesia sudah ada sejak lama, barangkali sejak Islam itu datang ke Indonesia. Pada awalnya bahasa Arab diajarkan sesuai kebutuhan umat Islam sebagai bahasa ibadah, bahkan sampai sekarang banyak orang Indonesia yang bisa berbahasa Arab dalam fungsinya sebagai bahasa ibadah, baru kemudian bahasa arab diajarkan untuk memahami sumber-sumber agama seperti al-Qur'an, Hadist, tafsir dan sebagainya. Sejauh ini belum ada hasil penelitian yang memastikan sejak kapan studi bahasa Arab di Indonesia mulai dirintis dan dikembangkan. Asumsi yang selama ini berkembang adalah bahwa bahasa Arab sudah mulai dikenal oleh bangsa Indonesia sejak Islam dikenal dan dianut oleh mayoritas bangsa kita. Jika Islam secara meluas telah dianut oleh masyarakat kita pada abad ke-13, maka usia pendidikan bahasa arab dalam bentuk yang paling sederhana-- dipastikan sudah lebih dari 7 abad. Karena

\footnotetext{
${ }^{1}$ Penulis adalah Dosen Bahasa Arab pada UIN Maliki Malang.
} 
perjumpaan umat Islam Indonesia dengan bahasa Arab itu paralel dengan perjumpaannya dengan Islam. Dengan demikian, bahasa Arab di Indonesia jauh lebih dulu ada dibandingkan dengan bahasa asing lainnya, seperti: Belanda, Inggris, Portugal, Mandarin, dan Jepang.

Bahasa Arab di Indonesia saat ini sudah diajarkan mulai dari TK (sebagian) hingga perguruan tinggi. Berbagai potret penyelenggaraan pendidikan bahasa Arab di lembaga-lembaga pendidikan Islam setidaknya menunjukkan adanya upaya serius untuk memajukan sistem dan mutunya. Secara teoritis menurut Dr. Muhbib (2008 : 105 - 106) paling tidak ada empat orientasi pendidikan bahasa Arab sebagai berikut:

1. Orientasi Religius, yaitu belajar bahasa Arab untuk tujuan memahami dan memahamkan ajaran Islam ( $f a h m$ al-maqrû'). Orientasi ini dapat berupa belajar keterampilan pasif (mendengar dan membaca), dan dapat pula mempelajari keterampilan aktif (berbicara dan menulis).

2. Orientasi Akademik, yaitu belajar bahasa Arab untuk tujuan memahami ilmuilmu dan keterampilan berbahasa Arab (istimâ', kalâm, qirâ'ah, dan kitâbah). Orientasi ini cenderung menempatkan bahasa Arab sebagai disiplin ilmu atau obyek studi yang harus dikuasai secara akademik. Orientasi ini biasanya identik dengan studi bahasa Arab di Jurusan Pendidikan bahasa Arab, Bahasa dan Sastra Arab, atau pada program Pascasarjana dan lembaga ilmiah lainnya.

3. Orientasi Profesional/Praktis dan Pragmatis, yaitu belajar bahasa Arab untuk kepentingan profesi, praktis atau pragmatis, seperti mampu berkomunikasi lisan (muhâadatsah) dalam bahasa Arab untuk bisa menjadi TKI, diplomat, turis, misi dagang, atau untuk melanjutkan studi di salah satu negara Timur Tengah, dsb

4. Orientasi Ideologis dan Ekonomis, yaitu belajar bahasa arab dengan tujuan untuk memahami dan menggunakan bahasa arab sebagai media kepentingan orientalisme, kapitalisme, imperialisme,dsb. Orientasi ini bisa dilihat diantaranya dengan dibukanya beberapa lembaga kursus dan institusi studi bahasa arab di beberapa negara barat seperti ma'had al-Dirasat al-Syarqiyah di Universitas Leipzig Jerman

Kebanyakan kurikulum PBA pada UIN, IAIN, dan STAIN merupakan hasil "ijtihad institusional" masing-masing, bukan merupakan "ijtihad struktural" (baca: Depag RI). Sejauh ini belum pernah ada konsensus atau kesepakatan bersama mengenai pentingnya kerjasama atau networking antar PBA untuk merumuskan epistemologi, arah kebijakan, dan kurikulum PBA secara lebih luas dan komprehensif. Meskipun PBA FITK menjadi semacam "lokomotif atau kiblat" bagi PBA-PBA lainnya -antara lain karena berada di pusat dan menjadi sasaran studi banding bagi PBA-PBA lainnya-namun tuntutan dan kebutuhan untuk memperbaharui kurikulumnya sudah semakin mendesak, karena perkembangan ilmu-ilmu bahasa Arab, sains, teknologi, dan sistem sosial budaya cukup pesat.

Dalam masyarakat dewasa ini mulai timbul keluhan atau kritik yang dialamatkan kepada dunia pendidikan tinggi Islam, termasuk PBA, bahwa lulusan PBA kurang memiliki kemandirian dan keterampilan berbahasa yang memadai, sehingga daya saing mereka rendah dibandingkan dengan alumni lembaga lain. Kelemahan daya saing ini perlu dibenahi dengan memberikan aneka "keterampilan plus", seperti: keterampilan berbahasa Arab dan Inggris aktif (berbicara dan 
menulis), keterampilan mengoperasikan berbagai aplikasi komputer, keterampilan meneliti, keterampilan manajerial, dan keterampilan sosial (Muhbib, 2012).

\section{B. Kurikulum Bahasa Arab}

Menurut Abdullah (2010) sampai saat ini belum ada teori kurikulum yang diterima oleh semua orang disebabkan karena dua hal; Pertama, karena belum ada definisi kurikulum yang disepakati oleh semua orang. Kedua, belum jelas mengenai batas-batas materi yang menjadi wilayah penelitiannya. Hal ini tidak hanya ditemukan dalam teori kurikulum, tapi hampir pada seluruh bidang ilmu sosial sering ditemukan bias ini, karena ilmu-ilmu sosial terus berkembang sesuai dengan perkembangan manusia. Teori sosial bukan merupakan hal yang statis, ia tidak stabil, selalu berkembang mengikuti perkembangan masyarakat, sains dan teknologi (Collin J, 1999). Karenanya dalam merumuskan kurikulum, hendaknya selalu berpijak kepada keadaan masyakarat, ia tidak boleh statis, harus selalu mampu memenuhi kebutuhan masyarakat. Kurikulum yang ada di Indonesia pun terus berubah, kurikulum yang digunakan sebelum dan sesudah kemerdekaan tidak sama, karena kebutuhan masyarakat telah berubah, bahkan ia berkembang dengan sangat cepat setelah Indonesia melewati masa reformasi. Ada banyak kurikulum yang telah digunakan di indonesia, di antaranya:Rencana Pelajaran 1947, Rencana Pelajaran Terurai 1952, Kurikulum 1968, Kurikulum 1975, Kurikulum 1984, Kurikulum 1994 dan Suplemen Kurikulum 1999, Kurikulum 2004 (KBK), KTSP 2006 (Abdullah Idi, 2010).

Kurikulum merupakan salah satu bentuk perubahan dalam rangka memperbaiki proses pendidikan agar tercipta efektifitas yang menjadi suatu kombinasi input dan output sekolah. Perkembangan kurikulum merupakan suatu hal yang penting karena kurikulum bagian dari program pendidikan. Tujuan utamanya adalah meningkatkan kualitas pendidikan dan bukan semata-mata hanya menghasilkan suatu bahan pelajaran. Untuk mencapai tujuan pendidikan yang ditetapkan, kurikulum harus disusun secara strategis dan dirumuskan menjadi program-program tertentu. Karena harus selalu relevan dengan perubahan masyarakat, penyusunan kurikulum harus mempertimbangkan berbagai macam aspek seperti perkembangan anak, perkembangan ilmu pengetahuan, perkembangan kebutuhan masyarakat dan lapangan kerja dan sebagainya. Selain itu juga mesti dilakukan pendekatan-pendekatan terhadap kurikulum yang bertujuan untuk memudahkan dalam penerapannya. Serta mesti dibuat model-model pengembangan kurikulum yang disesuaikan dengan kondisi lingkungan serta kebutuhannya. Yang dimaksud pengembangan kurikulum adalah proses perencanaan dan penyusunan kurikulum oleh pengembang kurikulum (curriculum developer) dan kegiatan yang dilakukan agar kurikulum yang dihasilkan dapat menjadi bahan ajar dan acuan yang digunakan untuk mencapai tujuan pendidikan nasional.

Demikian juga dalam penyusuanan kurikulum bahasa arab, hendaknya pembuat kurikulum melihat ia dari berbagai aspek, pembuat harus melihat kebutuhan siswa, masyarakat dan pelaku pendidikan. Bahasa arab jangan hanya dilihat sebagai bahasa agama. Ia juga harus dilihat sebagai bagian dari bahasa dunia. Semenjak adanya pengakuan masyarakat Internasional terhadap bahasa Arab, maka semakin jelas bahwa bahasa arab menempati posisi penting dalam percaturan internasional. Masyarakat internasional terutama negara-negara maju seperti Eropa dan Amerika Serikat, mulai tertarik untuk mempelajari sekaligus menggunakan bahasa ini sebagai media komunikasi. 
Arti semua itu adalah, bahwa bahasa Arab telah menjadi bahasa ilmiah, akademis, dan sekaligus bahasa populer masyarakat internasional. Dengan demikian mempelajari bahasa Arab sebagai alat menyampaikan kebenaran ilmu pengetahuan, dengan sendirinya menjadi sangat penting. Dalam perspektif ini, Perguruan Tinggi Agama Islam (PTAI) yang menggunakan bahasa arab sebagai alat untuk memahami teks asli ajaran agama maupun alat komunikasi bagi sivitas akademikanya, hendaknya melihat bahasa arab juga secara fungsional.

Di sini tampak jelas, bahwa semua orang yang belajar atau mengajar di perguruan tinggi Islam khususnya, sudah semestinya mengerti, memahami dan menguasai bahasa Arab. Bahkan untuk perguruan tinggi umum sekalipun dalam kasus mata kuliah dan literatur tertentu yang menggunakan bahasa arab, maka dengan sendirinya harus mengetahui dan harus menguasai bahasa arab tersebut. Semisal sekarang banyak kampus-kampus umum yang membuka jurusan perbankan syariah atau ekonomi islam. Di universitas Brawijaya untuk Jurusan Ekonomi Islam sudah diajarkan bahasa arab, meskipun masih pada tingkatan yang sederhana. Selain itu di beberapa Sekolah Tinggi Ilmu Kesehatan (STIKES) juga sudah ada beberapa yang memberikan mata kuliah bahasa arab sebagai penunjang profesi profesi. Karena beberapa negara Arab seperti Abu Dhabi, Qatar dan beberapa kawasan teluk sangat berminat untuk mengambil perawat dari Indonesia. Oleh karena itu, sangat ironis memang, kalau ada Perguruan Tinggi Agama Islam yang di dalamnya tidak ada nuansa arabnya, apalagi sivitas akademikanya tidak diwajibkan untuk menggunakan bahasa Arab sebagaimana diwajibkannya bahasa yang lainnya.

Hanya saja pembelajaran bahasa arab di PTAI masih banyak yang menggunakan metode tradisional yang kebanyakan masih fokus kepada kaidahkaidah bahasa dan menterjemah dan mengajarkan bahasa arabs secara parsial dan tidak melihat perkembangan dan kebutuhan jaman. Setelah ditemukan banyak kelemahan dalam kurikulum bahasa arab pada sejumlah lembaga pendidikan Islam tradisional, maka banyak dijumpai kritik terhadap metode yang digunakan. Kritik tersebut tertuju pada metode pembelajaran bahasa yang diterapkan secara parsial atau terpisah-pisah. Akibatnya ilmu kebahasaan yang diterima oleh para siswa juga bersifat parsial. Padahal ilmu bahasa itu merupakan satu kesatuan yang tidak dapat dipisah-pisahkan satu sama lain. Antara kemampuan mendengar (الاستماع), berbicara (الكلام), membaca (القراءة) dan menulis (الكتابة) tidak dapat dipisah-pisah. Demikian pula antara perbendaharaan kata, pembentukan kata, dan penyusunan kalimat, satu sama lain tidak dapat dipisah-pisahkan. Akibatnya banyak dijumpai siswa yang menguasai ilmu bahasa seperti, sharaf, nahwu dan kosakata secara hapalan, sementara aplikasinya kurang mampu dan kurang baik. Oleh karena itu, dalam proses pembelajaran bahasa Arab mulai muncul strategi dan metode baru, yaitu apa yang disebut dengan metode kesatuan atau unit/ نظرية الوحدة (All in one system) (Ibrahim, 1964 : 50-52). Dengan metode ini, bahasa dikaji dari berbagai aspeknya dalam satu wacana tertentu, sehingga belajar bahasa terasa sebagai satu kesatuan yang utuh, bukan bagian-bagian yang terpisah-pisah. Dengan metode ini pula pembelajar bahasa diharapkan dapat memperoleh berbagai keterampilan bahasa, atau dapat memperoleh berbagai pengetahuan tentang bahasa dalam waktu yang sama.

Metode kesatuan yang berorientasi pada pembelajaran bahasa sebagai satu kesatuan yang utuh, terkait dengan aspek-aspek kebahasaan itu sendiri baik dalam 
hal keterampilan-keterampilan berbahasa maupun pengetahuan-pengetahuan bahasa. Oleh karena itu strateginya harus merepresentasikan semua aspek tersebut, tidak hanya difokuskan pada aspek tertentu saja. Sebagai konsekuensi dari tuntutan tersebut, maka metode kesatuan dalam oprasinalnya melibatkan aspek-aspek berikut: (Effendi, 2003 : 100)

1. Istima' (Menyimak/Listening)

Aspek ini menitikberatkan pada pendengaran langsung dari guru tentang cara-cara melafalkan kata-kata atau kalimat berbahaa Arab secara fasih dan benar, sekaligus sambil memahami artinya. Dengan aspek ini, siswa diharapkan memilki kemampuan dan keteampilan dasar dalam berbahasa Arab, yaitu keterampilan mendengarkan. Dalam hal ini guru memainkan peranan yang sangat penting, maka dia dituntut bisa menyajikan materi dengan sebaik-baiknya dan memberikan contoh yang jelas kepada para siswa, sehingga mereka bisa menirukan secara benar (Syahatah, 1993).

Siswa yang bukan penutur asli biasanya lemah dalam ketrampilan ini, apalagi jika mereka tidak tinggal di suatu lingkungan bahasa. Kelemahan ini tidak hanya terjadi dalam bahasa arab, bahkan bahasa asing lainnya. Bahkan siswa yang sudah tinggal di lingkungan bahasa sekalipun sering masih merasakan kesulitan ketika harus mendengarkan ucapan penutur asli. Karenanya agar siswa baik dalam ketrampilan ini mereka harus dihadirkan dalam lingkungan yang ada penutur aslinya atau sering melihat tayangan-tayangan penutur asli bahasa arab, semisal chanel al-Jazira, Saudi, Sudan, Bahrain, dsb.

2. Kalam (berbicara/Speaking)

Kegiatan berbicara atau bercakap mempunyai aspek komunikasi dua arah, yakni antara pembicara dengan pendengarnya secara timbal balik. Dengan demikian latihan berbicara harus terlebih dahulu didasari oleh: (a) kemampuan mendengarkan, (b) kemampuan mengucapkan, dan (c) penguasaan kosa kata dan ungkapan yang memungkinkan siswa dapat berkomunikasi.

Aspek ini menitikberatkan pada latihan berbicara dan bercakap-cakap dengan berbahasa Arab. Dalam prakteknya bisa dilakukan antara guru dengan siswa atau anatara siswa dengan siswa. Apa yang telah diperdengarkan oleh guru kepada siswa mengenai kata-kata atau kalimat hendaknya dipraktekkan langsung oleh siswa dalam bentuk bicara atau percakapan baik secara berdua maupun kelompok kecil . Dalam kesempatan yang lain, mereka juga diminta untuk berbicara langsung dengan penutur asli, agar mereka memiliki pengalaman yang lain dalam kemampuan kalam. Karena terkadang ada orang yang pintar berbicara bahasa arab dalam lingkungan tertentu tapi tidak bisa difahami ketika berbicara langsung dengan penutur asli bahasa tersebut. Selain itu, hal ini untuk melatih kepercayaan siswa dan memberikan motivasi yang lebih kepada mereka.

3. Qira'ah (Membaca/Reading)

Barangkali ketrampilan inilah yang paling banyak dikuasai oleh siswa indonesia. Karena semenjak awal datangnya bahasa arab ke Indonesia yang paling banyak diajarkan adalah ketrampilan berbahasa ini. Membaca sebagai salah satu aspek keterampilan berbahasa memiliki dua pengertian. Pertama, mengubah lambang tulisan menjadi bunyi. Kedua, menangkap arti dari seluruh situasi yang dilambangkan dengan lambang-lambang tulisan dan bunyi tersebut.

Esensi dari kemahiran membaca terletak pada aspek yang kedua, yaitu pemahaman. Namun, ini tidak berarti abhwa aspek yang pertama, yakni pengenalan 
lambang-lambang tulisan, tidak penting. Sebab kemahiran dalam aspek pertama mendasari kemahiran yang kedua. Betapa pun juga, keduanya merupakan tujuan yang hendak dicapai dalam pengajaran bahasa.

Kemampuan membaca sangat tergantung pada penguasaan kosakata dan gramatika. Oleh karena itu pada tingkat permulaan, teks bacaan masih perlu diberi syakal, dan secara bertahap dikurangi sesuai dengan perkembangan penguasaan kosa kata dan pola kalimat bahasa Arab oleh para siswa. Tetapi pada prinsipnya, sejak mula siswa dilatih dan dibiasakan membaca tanpa syakal dalam rangka membina dan mengembangkan kemampuan membaca untuk pemahaman (Ibrahim, 1964).

4. Kitabah (Menulis/Writing)

selain kemampuan menyimak, siswa-siswa indonesia juga masih sangat banyak yang keslulitan dalam menguasai kemampuan menulis. Kemampuan menulis dalam pembelajaran bahasa mempunyai dua aspek orientasi. Pertama, kemahiran membentuk huruf dan menguasai ejaan. Kedua, kemahiran mengungkapkan fikiran, gagasan dan perasaan dengan tulisan. Dalam pengajaran bahasa, inti kemahiran menulis terletak pada aspek kedua, meskipun tidak berarti bahwa aspek pertama diabaikan. Dalam prosesnya, kedua aspek tersebut harus dilatihkan secara baik dan simultan.

Latihan menulis ini pada prinsipnya diberikan setelah latihan menyimak, berbicara dan membaca. Ini tidak berarati bahwa latihan menulis ini hanya diberikan setelah siswa memiliki ketiga kemahiran tersebut. (al-Khully, 2002). Latihan menulis dapat diberikan pada jam yang sama dengan latihan kemahiran yang lain; sudah tentu dengan memperhatikan tahap-tahap latihan sesuai dengan tingkat kemampuan siswa.

Selain aspek-aspek keterampilan di atas yang harus diajarkan kepada siswa secara simultan sesuai dengan tuntutan metode kesatuan, juga hedaknya aspek-aspek kebahasaan lain yang bersifat keilmuan menjadi muatan dalam materi pembelajaran. Seperti halnya, materi nahwu dan sharaf, atau bahkan balaghah, meskipun dalam aplikasinya bisa bertahap sesuai dengan tingkat kemampuan siswa. Dengan mengajarkan berbagai aspek bahasa secara integral, baik bidang yang menyangkut keterampilan maupun keilmuan bahasa, maka pengajaran bahasa Arab dapat dirasakan sebagai sesuatu yang utuh dan komprehensif. Hanya saja kemampuan ini biasanya diberikan kepada siswa yang ingin menjadi ahli bahasa diajarkan difakultas adab atau humaniora-, tidak diberikan kepada siswa yang menjadikan bahasa arab sebagai bekal komunikasi atau pemahaman teks-teks arab.

\section{Implementasi Kurikulum d PTAI}

Implementasi kurikulum merupakan proses yang kedua dalam proses penyelenggaraan kurikulum. Pada awalnya kurikulum itu direncanakan, kemudian diterapkan lalu dievaluasi hasilnya. Secara gamblang Muhaimin (2005) menggambarkan sebagai berikut:

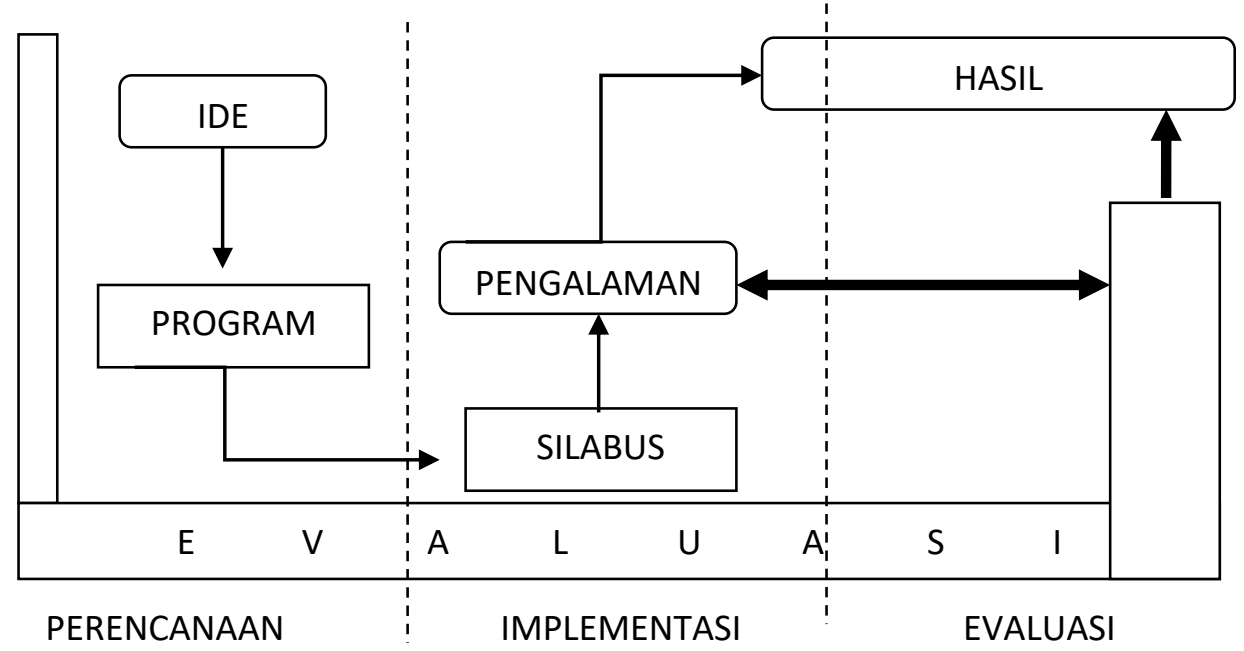


Implementasi kurikulum sebenaranya bukan satu kesatuan yang mandiri, ia merupakan kelanjutan dari perencaanaan yang dilakukan sebelumnya, yang kemudian akan ditutup dengan evaluasi yang menyeluruh meskipun pelaksaan evaluasi itu dilaksanakan dengan terus menerus. Ketiganya digabungkan sebagai satu kesatuan yang saling mendukung antara satu dengan lainnya. Begitu juga penerapan kurikulum di PTAI, ia merupakan proses kelanjutan dari perencanaan. Dalam implementasinya ia tetap diawali dengan perencanaan mengenai kebutuhan siswa dan PTAI penyelenggara. Sehingga kurikulum yang dihasilkan merupakan pemenuhan dari kebutuhan yang ada. Menurut Peratutan Pemerintah Nomor 60 tahun 1999 tentang Pendidikan Tinggi, pasal 1 (2) bahwa Perguruan Tinggi adalah satuan pendidikan yang menyelenggarakan pendidikan tinggi. Tujuan perguruan tinggi dalam menyelenggarakan pendidikan tinggi adalah: Pasal 2 (1) 1. Menyiapkan peserta didik menjadi anggota masyarakat yang memiliki kemampuan akademik dan/atau profesional yang dapat menerapkan, mengembangkan dan/atau menciptakan IPTEK dan /atau kesenian dan budaya. 2. Mengembangkan, menyebarluaskan IPTEK dan/atau kesenian serta mengupayakan penggunaannya untuk meningkatkan tarap kehidupan masyarakat dan memperkaya kebudayaan nasional.

Dari uraian di atas tampak jelas, bahwa tugas Perguruan Tinggi merupakan produsen atau tempat yang memproses manusia Indonesia yang memiliki kualitas sebagai ilmuwan, profesional, pengembang dan penyebar IPTEK, dan sekaligus penerap IPTEK kepada masyarakat. Sementara itu, arah yang akan dicapai dalam proses pendidikan nasional, adalah terwujudnya manusia Indonesia yang beriman dan bertakwa kepada Tuhan Yang Maha Esa, berbudi tinggi dan menguasai IPTEK serta mensejahterakan masyarakat, maka posisi perguruan tinggi -termasuk didalamnya perguruan tinggi Agama Islam - adalah sangat Urgen. Mengingat sistem nilai yang diterapkan di perguruan tinggi syarat dengan moralitas Agama, maka pembelajaran Agama dengan ilmu bantunya (bahasa Arab) merupakan kewajiban yang harus dilaksanakan.

Dengan demikian, perbedaan antara Perguruan Tinggi Umum dan Perguruan Tinggi Agama Islam adalah terletak pada SDM dan materi kajiannya. Perbedaan materi kajian itu sendiri hendaknya didesain sedemikian rupa sehingga Perguruan Tinggi Agama Islam mempunyai peran ganda mencetak sarjana dan sekaligus Ahli Agama, seperti dalam semboyan ulul albab UIN malang yaitu menjadi ulama yang intelek dan intelek yang ulama. Keberpaduan dua hal ini, dimana didalamnya mengandung unsur-unsur iman, ilmu dan amal menjadi citacita bagi lulusan Perguruan Tinggi Agama Islam di Indonesia.

Mengingat posisi dan peran Perguruan Tinggi Agama Islam yang begitu penting dalam upaya mempersiapkan mahasiswa menjadi manusia yang utuh antara jasmani dan rohani -insan ulul albab-, maka studi ilmu-ilmu keislaman hendaknya dilakukan dengan menggunakan bahasa transformasi teks agama yang asli yaitu bahasa Arab.

Dalam penyelenggaran pengajaran bahasa arab di PTAI bahasa desain kurikulum bisa disandarkan pada tiga hal:

1. Subjek Center Design: kurikulum ini dibuat dalam rangka mengembangkan ilmu bahasa arab. Model ini bisa dilaksanakan di jurusan bahasa arab di PTAI di indonesia, biasanya materi yang diajarkan adalah ilmu kebahasaan seperti 'Ilmu Al-Lugoh, Balaghoh, Nahwu, Sharaf, Dilalah, Ashwat, Naqdul Khitab, 
'Ilmu Al-Ma'ajim, disamping juga mengajarkan empat ketrampilan berbahasa yaitu Maharah Al-Istima', Al-Kalam, Al-Qira'ah, Al-Kitabah.

2. Learner Center Design: kurikulum yang dibuat lebih fokus kepada siswa, kurikulum ini dibuat berdasar pada minat dan kebutuhan siswa. Di PTAI penyelenggara model kedua ini biasanya dala Self Acces center (SAC) dimana siswa dapat memilih berdasar kebutuhannya akan bahasa. Di SAC disediakan media-media yang bisa dipilih oleh siswa sesuai dengan kemauan dan keinginan siswa. Pembelajaran di unit ini bersifat mandiri, hanya ada petugas yang memberikan panduan dan bimbingan secara terbatas. Siswa dituntut untuk lebih mengaktualisasi kemampuannya sendiri. Ia bisa menonton film adalam bahasa arab, membuka kamus online, permainan-permainan bahasa yang bisa meningkatkan kemampuan berbahsanya.

3. Problem Center Design: kurikulum ini merespon isu-isu terkini yang masih hangat dan aktual. Siswa diajak untuk menganalisa, memahami, dan menguasai permasalahan kekinian. Materi ajar model ini berisi tema-tema yang serumpun. Seluruh isi pelajaran dalam satu unit mengarah kepada tema yang sama, ketrampilan apapun yang diajarkan. Maka empat ketrampilan membahas satu tema yang berisi pembahasan yang sama. Semisal bahasan yang dibahas adalah tentang lingkungan maka seluruh materi mulai dari istima', kalam, qira'ah dan kitabah berisi materi yang membahasa tentang lingkungan. Model buku yang seperti ini kita temukan dalam kitab Al-'Arabiyah Baina Yadaik yang membagi setiap bahasannya dibagi ke dalam unit-unit atau wihdah yang membahas tema tertentu.

Akan tetapi, kalau kita melihat realita yang ada, pengajaran bahasa arab di PTAI di Indonesia, masih banyak yang menggunakan kurikulum tradisional dalam mengajarkan kemahiran berbahasa. Bahkan di UIN Malang pun di unit program pengembangan bahasa arab masih berkutat pada metode dan cara tradisional, yakni untuk tujuan-tujuan keagamaan dengan penekanan pada aspek penguasaan grammar dan keahlian menterjemah, meskipun sudah menggunakan ABY sebagai materi ajarnya, ia tidak mengutamakan empat kecakapan dalam berbahasa seperti kitabah, istima' dan kalam, masih memberikan fokus yang lebih banyak kepada qira'ah saja. Sehingga hasil dari proses pembelajaran siswa tidak maksimal. Padahal mereka diberikan intensif bahasa arab selama satu tahun penuh.

Penulis rasa untuk masa sekarang ini, sistem pengajaran dengan model kurikulum seperti ini - hanya fokus kepada satu ketrampilan saja-tidak lagi relevan, sebab bahasa Arab sebagai bahasa internasional tidak lagi hanya berfungsi sebatas bahasa agama, akan tetapi telah menjadi media komunikasi dalam seluruh aspek kehidupan. Yang mana konsekuensinya, bahasa Arab tidak lagi cukup hanya dikuasai secara pasif dalam bentuk penguasaan grammar dan keahlian menterjemah, akan tetapi harus dikuasai secara komunikatif, baik lisan maupun tulisan. Bahkan masih banyak dikalangan masyarakat kita bahwa orang yang hebat -ahli agama- itu, yang hafal sekian bait dari kitab Imrithi atau Al-Fiyah. Orang yang demikian akan dianggap mumpuni dalam bahasa arab meskipun tidak bisa berbicara bahasa arab dengan fasih.

Diketahui bahwa Kurikulum tradisional memberikan porsi yang sangat besar terhadap kaidah-kaidah bahasa arab daripada kemampuan yang lain, makannya di pondok-pondok salaf kita menemukan kitab al-'awamil, matan alJurumiyah, mutammimah, nadzm 'imrithi, nadzm maqsud, dan Al-Fiyah diajarkan 
dengan sangat intensif. Belum lagi diajarkan sharaf seperti Al-Amstilah AtTashrifiyah, Kaelani, Qawaidus-Sharfiyah, dsb. Semua itu menjadi bukti tentang adanya grammar-oriented yang sangat kuat dalam pembelajaran bahasa arab di Indonesia. Pada awal-awal bahasa arab diajarkan metode ini memang sangat diminati, barangkali ia adalah metode yang paling tua dalam pengajaran bahasa arab (Thu'aimah, 1989). Hal yang demikian ini juga berimbas pada pembelajaran bahasa arab di kampus-kampus islam, karena kebanyakan pengajar-pengajar di PTAI juga lulusan pesantren yang ketika mereka belajar di sana menggunakan metode itu.

Dengan adanya fenomena di atas, saat ini kampus-kampus islam hendaknya memiliki warna baru dalam pengajaran bahasa arab, sehingga mahasiswamahasiswa yang belajar bahasa arab mampu mengaktualisasi kemampuan bahasa arabnya dalam segala bidang; ia pandai membaca kitab-kitab turost dan dan sumber-sumber hukum islam serta memahaminya dengan benar, teteapi selain kemampuan itu ia juga memiliki kemampuan mendengar yang baik dan kemampuan berbicara yang fasih. Semua itu tidak mungkin didapat jika kampuskampus islam masih berpegang teguh dengan kurikulum tradisional.

Seiring dengan berjalannya waktu, beberapa pondok dan kampus Islam sudah mulai merubah konsep pengajaran bahasa arab. Di ranah pesantren kini kita melihat sudah banyak pesantren -yang kemudian dikenal pesantren modern-yang menerapkan pengajaran bahasa arab dengan kurikulum modern. Kurikulum modern memakai metoder yang bervariatif semisal Direct Method, Intensive Metod, AudioVisual Method, Audio Lingual method with Integrated Approach (Shinni, 1985). Di dunia pesantren mungkin pondok Gontor-lah yang menjadi pioneer dalam pengajaran bahasa arab modern, sampai sekarang kita bisa lihat dan rasakan keberhasilan pengajaran bahasa arab yang dilakukan oleh Gontor meski tidak bisa kita bilang tanpa kelemahan.

Selain di dunia pesantren, beberapa kampus juga menerapkan metode modern dalam pengajaran bahasa arab, ia tidak lagi hanya fokus kepada kaidahkaidah bahasa arab tapi sudah menfokuskan kepada empat kemahiran berbahasa; istima', kalam, qira'ah dan kitabah. Misalnya beberapa UIN dan beberapa kampus PTAI yang memiliki unit tersendiri untuk pengembangan bahasa arab. UIN malang dianggap cukup berhasil dalam mengembangkan program ini, terbukti model ini kemudian banyak ditiru oleh PTAI lain di indonesia. Meski kemudian dalam perjalanannya juga mengalami banyak hambatan dan hasil yang tidak maksimal. Progma Khusus Perkuliahan Bahasa Arab (PKPBA) yang dijalankan UIN malang beberapa kali pernah mengganti bahan ajar, karena dianggap tidak lagi relevan dengan jaman. Ini sebagai jawaban atas kebutuhan masyarakat akan bahasa arab, juga sebagai respon semakin berkembangnya dinamika bahasa arab. Pada awalnya unit ini menggunakan al- 'arabiyah linnasyi'in, kemudian al-arabiyah baina yadaik dan sekarang PKBA dalam rencana dan penyusuna buku tersendiri yaitu silsilah allughoh al-arabiyah li aghrodin khos. Pada waktunya nanti, PKPBA akan menggabungkan antara one all system dengan menggunakan kitab al-arabiyah baina yadaik (ABY) pada tahap 1 dan 2, lalu dilanjutkan dengan Al- Lughoh Al'Arabyah Li Aghrodin Khoshshoh: Silsilah Fi Ta'limi Al-Lughoh Al-Arabiyah Li Al-Nathiqina Bi Al-Lughotin Ukhra (Arabic for special purposes) pada tahap 3 dan 4. Penggunaan dengan Al- Lughoh Al-'Arabyah Li Aghrodin Khoshshoh: Silsilah Fi Ta'limi Al-Lughoh Al-Arabiyah Li Al-Nathiqina Bi Al-Lughotin Ukhra ini sudah 
dikelompokan berdasar pada fakultas masing-masing karenanya sementara ini ada 6 silisilah yang dibuat yaitu: silsilah al-lughoh al-arabiyah li al-'amilina fi majali sihhi, silsilah al-lughoh al-arabiyah li al-'amilina fi majali iqthishodi, silsilah allughoh al-arabiyah li al-'amilina fi majali ilmin nafsi, silsilah al-lughoh alarabiyah li al-'amilina fi majali al-ulum, silsilah al-lughoh al-arabiyah li al'amilina fi majali insaniyah wa at-tsaqofah, dan silsilah al-lughoh al-arabiyah li al- 'amilina fi majali ilmi at-tarbiyah.

D. Impelentasi dan Manajemen Bahasa Arab di PKPBA UIN Maliki Malang

Di bawah ini akan saya berikan contoh implemetasi dan manajemen bahasa arab di unit PKPBA. Contoh ini adalah salah satu dari tiga model implementasi pengembangan bahasa yang umumnya ada di perguruan tinggi. Biasanya bahasa arab di PT dijadikan sebagai subyek, learner center dan problem center. PKPBA merupakan contoh dari yang problem center dimana didalamnya bahasa dipelajari berdasar tema-tema tertentu yang dibagi ke dalam banyak kelompok tema. Saat ini PKPBA UIN Malang masih menggunakan kitab al-arabiyah baina yadaik sebagai materi ajarnya. Pembelajaran di unit PKPBA ini diberikan kepada seluruh mahasiswa dari jurusan apapun dengan kemampuan yang variatif. Diberikan dengan materi yang sama, beban yang sama dan ujian yang sama. Tentu dengan metode itu ditemukan banyak masalah dan ketimpangan dalam pengajaran dan prosesnya. Berikut ini contoh dari implementasi kurikulum bahasa arab di PKPBA UIN Maliki Malang.

1. Latar belakang

a. UIN malang menghadapi tantangan: menciptakan ulama yang intelek professional dan intelek professional yang ulama. Saat ini kita dituntut untuk menjawab kompleksitas persoalan dunia yang menuntut pendekatan interdisipliner.

b. UIN menjawab tuntutan global: memacu diri untuk menjadi salah satu PTAI terdepan menuju cita-cita sebagai pusat peradaban islam.

c. Rendahnya kemampuan bahasa arab: banyak cibitas PTAI masih rendah kemampuan bahasa arabnya, padahal ia menjadi identitas yang membedakan antarai PTAI dengan PTU.

d. Upaya meningkatkan bahasa arab: banyak usaha yang dilakukan oleh PTAI dalam rangka meningkatkan kemampuan bahasa arab, semisal dengan mensyaratkan menyerahkan sertifikat TOAFL untuk pengambilan ijazah, hanya saja UIN malang kemudian mengambil langkah untuk melaksanakan program intensif bahasa arab selama satu tahun.

e. Bahas arab sebagai syarat mutlak penguasaan ilmu-ilmu Islam: secara rasional seseorang tidak mungkin menguasai disiplin ilmu-ilmu keislaman tanpa memiliki kemampuan bahasa arab yang utuh.

2. Tujuan

a. Membangun kemampuan mahasiswa dalam bahasa arab untuk melakukan kajian keislaman

b. Membekali mahasiswa dengan kemampuan lisan maupun tulisan.

3. Bentuk Operasional

a. Program PKPBA ini dilaksanakan selama 12 bulan secara intensif

b. Dalam proses belajar mengajar diupayakan berbahasa arab

c. Waktu pelaksanaan selama 3 jam/hari dari hari senin samapi jum'at 
d. Materi perkuliahan dipilihkan yang berbahasa arab dan ditulis oleh penutur asli

e. Program ini dibina langsung oleh tim pengembang dalam bidang bahasa arab

f. Untuk melaksanakan program ini dibentuk tim khusus yang bertugas mengatur perkuliahan bahasa arab secara intensif

g. Untuk mendukung PKPBA ini diciptakan suasana yang kondusif, dimana kemampuan bahasa arab siswa tidak hanya menjadi tanggung jawab dosen bahasa arab tetapi seluruh dosen UIN malang. Oleh karena itu dosen bidang studi agama harus memacu kemampuan bahasa arab siswa dengan memberikan materi dan sumber tertulis dalam bahasa arab

h. Untuk memberikan metode pengajaran yang tepat sesuai kemampuan mahasiswa, maka perlu diadakan pengelompkan melalui plecement test

i. Jumlah setiap kelompok antara 30-35 orang

4. Struktur organisasi dan mekanisme kerja

a. Menakisme kerja: PKPBA merupakan lembaga yang diberi tanggung jawab untuk menangani perkuliahan bahasa arab. Dalam merealisasikan PKPNA, pimpinan UIN, pelaksanaan harian PKPA dengan semua staf, team teaching, wali kelas dan dosen bahasa arab adalah subyek sekaligus objek dalam pelaksanaan pengembangan bahasa. Hanya aspek struktural kelembagaan yang membedakan mereka.

b. Struktur organisasi: susunan struktur organisasi PKPBA adalah berikut:

- Pimpinan UIN: merupakan pencetus ide, penggerak, pemerhati, dan pembangun semangat semua program yang telah disepakati bersama.

- Tim bahasa: merekalah yang bertanggung jawab melaksanakan PKBA secara intensif, terdiri dari ketua dan sekretaris yang dibantu oleh badan Litbang, unit akademik, unit kesekretariatan, unit penerbitan dan penerjemahan, unit kemahasiswaan (FKM) dan seluruh dosen wali.

5. Pelaksanaan akademik

a. Bobot SKS:

- Semester 1

Maharah al-istima' : 2 SKS

Maharah al-kalam : 3 SKS

Maharah al-Qira'ah : 2 SKS

Maharah al-Kitabah : 2 SKS

- $\quad$ Semester 2

Maharah al-istima' : 2 SKS

Maharah al-kalam : 3 SKS

Maharah al-Qira'ah : 2 SKS

Maharah al-Kitabah : 2 SKS

b. Tujuan umum:

- Membekali siswa kemampuan berkomunikasi dengan bahasa arab secara lisan dan tulis

- Membekali siswa kemampuan membaca, memahami, dan menterjemahkan buku-buku atau kitab berbahasa arab untuk studi Islam.

c. Pendekatan

Pendekatan yang digunakan adalah integratif system yaitu suatu pendekatan yang melihat bahasa sebagai satu kesatuan yang utuh dan saling 
melengkapi, tidak terpisah-pisah. Pendekatan ini memberikan perhatian keempat kemaharian bahasa, yaitu kemahiran mendengar, berbicara, membaca, dan menulis secara seimbang. Selain itu, pendekatan ini juga memberikan perhatian terhadap unsur-unsur bahasa arab seperti bunyi huruf (al-Ashwath), kosa kata (mufradat), gramatikal (qawai'id), stressing (annabr), dan intinasi (tanghim).

d. Metode

Metode yang digunakan adalah metode eklektif (intiqaiyah) yaitu penggabungan antara beberapa metode yang dianggap paling tepat dan sesuai kondisi di kelas dengan tetap memperhatikan pendekatan komunikatif.

e. Model pembelajaran

Model pembelajaran yang dipraktikan adalah pembelajaran yang menyenangkan, menggembirakan dan membisakan. Hal ini dilaksanakan agar mahasiswa selalu termotivasi dalam upaya mempelajari bahasa arab. Model ini dilaksanakan dengan fleksibel dan bervariasi.

f. Tujuan dan teknik pengajaran

1) Istima'

a) Tujuan

- Menulis kata yang didengar dengan baik dan benar

- Mampu menulis pokok pikiran atau meringkas dari teks yang didengar

- Mengungkapkan kembali secara lisan dan tulisan dari teks yang didengar

- Membuat rangkuman dari teks yang didengar

- Membuat kesimpulan dari teks yang didengar

b) Tekhnik

- Mendengarkan dengan penuh perhatian

- Mendengarkan dan memahami

- Mendengarkan dan menirukan

- Demonstrasi dan menerapkan

2) Kalam

a) Tujuan

- Mampu menucapkan bunyi atau huruf dalam kalimat bahasa arab dengan makhraj dan intonasi yang tepat

- Mampu berkomunikasi dengan sesama atau orang asing dengan bahasa arab yang fasih

- Mampu mengekspresikan pikirannya melalui ungkapan dengan fasih

b) Teknik

- Melatih siswa untuk mengucapkan huruf atau kalimat dengan benar

- Melatih siswa menggunakan alat peraga dengan bahasa arab

- Membiasakan mahasiswa untuk merilis ungkapan atau cerita dengan menggunakan susunan bahasa arab

- Melatih mahasiswa untuk menjawab, mendiskusikan soal-soal serta memecahkan masalah-masalah dengan bahasa arab

- Demonstrasi melalui drama, dll. 
3) Qira'ah

a) Tujuan

- Mengenalkan huruf-huruf Arab dan tanda bacanya

- Melatih membaca dan memahami teks-teks arab dengan benar

- Melatih membaca dan memahami teks arab dengan benar

b) Tekhnik

- Mendengarkan dengan penuh perhatian

- Mendiskusikan isi teks

- Mendengarkan sambil memahami teks

- Membaca bersama-sama

- Membaca secara individu

4) Kitabah

a) Tujuan

- Membiasakan menulis dengan pola bahasa arab

- Mengembangkan kemampuan dalam mengekspresikan ide dengan media tulis

b) Tekhnik

- Kitabah al-khat

- Imla'

- Insya' muwajjah

- Insya hurry

g. Materi dan target Pelaksanaan: materi yang digunakan adalah kitab al'Arabiyah baina yadaiak jilid 1,2 dan 3, semua materi dalam kitab tersebut dihabiskan selama 1 tahun dengan dibagi kedalam empat tahap.

6. Evaluasi

Evaluasi dilaksanakan dalam bentuk tes tulis dan lisan. Test yang dilaksanakan antara lain:

a. Placement test: dilakukan sebelum masuk PKPBA bertujuan untuk mengelompokan siswa berdasarkan nilai.

b. Tes Tahapan: dilakukan untuk mengukur hasil pembelajaran bahasa arab pada tiap tahap dengan lisan dan tulisan. Test ini dilaksanakan selama empat kali dalam setahun dan materi yang diteskan adalah 4 ketrampilan berbahasa.

c. Test Terpadu: tes yang dilaksanakan pada akhir tahapan II dan IV dengan materi soal yang sama untuk semua kelas dalam bentuk tes tulis.

\section{E. Penutup}

Berdasar pada penjelasan di atas, maka kesimpulannya adalah sebagai berikut:

1. Masih banyak perguruan tinggi islam di Indonesia yang menggunakan metode tradisonal dalam mengajarkan bahasa arab, yaitu dengan memandang bahasa bukan sebagai satu kesatuan yang utuh, mereka masih mengajarkan bahasa arab secara parsial dan lebih banyak menggunakan pendekatan qawaid dan terjemah dalam mengajarkan bahasa arab.

2. Impelentasi bahasa arab di perguruan tinggi bisa dibagi ke dalam tiga kelompok besar, yaitu bahasa sebagai subjek (subjek center), siswa sebagai fokus bahasa (learner center), dan bahasa menjawab masalah kekinian (problem center). Subjek center dilaksanakan oleh jurusan bahasa arab baik 
pendidikan maupun murni, lerner center dilaksanakan oleh SAC (Self Acces Center), dan problem center dilaksankan oleh unit atau pusat bahasa.

3. Manajemen kurikulum di PTAI juga dikelompokan berdasar pada siapa yang menyelenggarakan pembelajaran bahasa arab, jika ia merupakan jurusan maka tanggung jawab manajemen diberikan kepada jurusan dan fakultas masingmasing, sementara jika yang menyelenggarakan adalah SAC dan unit atau pusat bahasa maka tanggung jawab manajemen diberikan kepada direktur atau kepala SAC dan unit masing-masing, yang kesemuanya di bawah komando pimpinan universitas. 


\section{DAFTAR PUSTAKA}

'Abdul 'Alim Ibrahim. 1964. Muwajjih al-Fanny Li Mudarris al-Lughah al-'Arabiyah. Mesir: Daar al-Ma’arif

Ahmad Fuad Efendi. 2003. Metodologi Pengajaran bahasa Arab. Malang: Misykat

Abdullah Idi. 2010. Pengembangan Kurikulum: Teori dan Praktek. Yohyakarta: ar-Ruz Media

Mulyasa, E. 2006. Kurikulum yang Disempurnakan: Pengembangan Standar Kompetensi dan Kompetensi Dasar. Bandung: PT Remaja Rosdakarya

Frazee, M. Bruce and Rose A. Rudnitski. 1995. Integrated Teaching Methods: Theroy, Classrom Application, and Field-Based Connections. USA: Delmar Publishers

Hasan Syahanah. 1993. Ta'lim al-Lughoh al-'Arabiyah Baina al-Nadzariyah wa alTathbiq. Kairo: Darul Misriyah al-Libnaniyyah

Muhaimin. 2005. Pengembangan Kurikulum Pendidikan Islam di Sekolah, Madrasah dan Perguruan Tinggi. Cet-4. Jakarta: PT RajaGrafindo Persada . 2003. Wacana Pengembangan Pendidikan Islam. Surabaya: Pusat Studi Agama, Politik, dan Masyarakat (PSAPM)

Wahab Muhbib Abdul. 2008. Epistemologi dan Metodologi Pembelajaran Bahasa Arab. Jakarta: UIN Jakarta Press

. Quo Vadis Pendidikan Bahasa Arab di Era Globalisasi. Makalah disampaikan dalam Seminar Sehari BEMJ PBA FITK UIN Jakarta, 29 Mei 2006.

- Tantangan dan Prospek Pendidikan Bahasa Arab Di Indonesia. http//:www.atida.org

- Revitalisasi Pengembangan Kurikulum Pendidikan Bahasa Arab di Era Postmetode dalam Perspektif Epistemologi. Makalah disampaikan dalam Seminar Nasional Fakultas Humaniora dan Budaya UIN Maliki Malang, 17 Maret 2012

Muh. Ali Al-Khuliy. 2002. Asalib Tadris Lughah al- 'Arabiyah. (Terj. Yayan Nurbayan, Model Pembelajaran Bahasa Arab). Bandung: PSIBA-UPI

Mahmud Isma'il Shinni. 1985. Dirasah fi Tharaiqi al-Lughot al-Ajnabiyah. Makalah dalam Waqai' Nadawat Ta'limul al-Lughoh al-'Arabiyah li Ghoiri al-Nathiqina biha. Juz 3. Maktabah al-Tarbiyyah al-'Arabiy li Duwali al-Khalij

Marsh, Collin J. 1999. Curricullum: alternetive, approaches, ongoing issues, 2 nd ed. USA: McGraw-Hill Book Company

Mahmud Kamil an-Naqoh dan Rusydi Ahmad Thu'aimah. 2003. Tharaiq Tadris alLughoh al- 'Arabiyah Lighoiri an-Natihiqina Biha. Rabat: ISESCO

Peraturan Pemerintah Republik Indonesia. Nomor 60 Tahun 1999. Tentang Pendidikan Tinggi. Depdiknas RI. Jakarta, 1999

Rusydi Ahmad Thu'aimah. 1989. Ta'lim al-'Arabiyah lighoiri al-Nathiqina Biha: Manahijuhu wa Asalibuhu. Rabat: ISESCO 
2001. Manahij Tadris al-Lughoh al-'Arabiyah bi al-Ta'lim al-Asasi. Kairo: Dar al-Fikr al-'Arabi

Slamet Daroini. 2007. Tadrisul Maharah al-Kalam li Thullabi al-Lughoh al-'Arabiyah li Ghoiri al-Nathiqina Biha. Majalah al-Hujum Vol. 3, No. 2, Tahun 2007

Sutaman. 2008. Al-Thariqoh al-Sam'iyyah al-Syafawiyah fi Ta'lim al-Lughoh al'Arabiyah. Majalah al-Hujum Vol. 4, NO. 2, Tahun 2008

Tim PKPBA. 2005. Pedoman Program Khusus Perkuliahan Bahasa Arab. UIN Malang 